\title{
A study on sales growth and market value through supply chain
}

\author{
Ahmed Nahar Al-Hussaini ${ }^{a^{*}}$
}

${ }^{a}$ The Public Authority for Applied Education \& Training, The College of Business Studies, State of Kuwait

\begin{tabular}{l}
\hline C H R O N I C L E \\
\hline Article history: \\
Received November 5, 2018 \\
Accepted December 42018 \\
Available online \\
December 42018 \\
\hline Keywords: \\
Business performance \\
Supply chain \\
Sales growth \\
Market value \\
Kuwait
\end{tabular}
\begin{abstract}
A B S T R A C T
This paper examines the effect of supply chain on performance indicators including sales growth and market value in the context of manufacturing firms in Kuwait. The dimensions of supply chain; namely strategic supplier partnership, information sharing, and information quality are also added in the model. Along with sales growth and market value, industry leadership, future outlook, overall response to competition, overall business performance, employee's productivity, process productivity, and success rate in the launching of new product are some of the important indicators for measuring firms' performance. Both factor analysis and structural equation modelling approaches are applied to the sample of 314 respondents taken from the manufacturing firms in Kuwait. Factor analysis provides some evidence that all the indicators for supply chain and business performance can be considered for the structural modelling and regression analysis. The core findings under structural modelling indicate that both strategic supplier partnership and information sharing had positive and significant impacts on the overall business performance. However, information quality appears to be the insignificant determinant of business performance. For the sales growth and market value, strategic supplier partnership and information sharing are significant determinants obtained through the regression analysis. The originality of the study can be viewed with reference to the selected performance measures and their determination through supply chain management. However, this study is confined only to the manufacturing sector and the services sector can be focused by incorporating additional performance measures and suitable sample size in future studies.
\end{abstract}

C) 2019 by the authors; licensee Growing Science, Canada

\section{Introduction}

For economic and financial growth, the manufacturing sector is considered to be the key role player. In order to assess economic development, the impact of this sector has been recorded both in domestic and international environment (Turner, 1988). With industrialization, developed countries around the globe are heavily dependent on financial development with the strategic objectives and progress (Reed, 2002). Subject to a firm, the idea of performance is not only a significant gauge to understand the present situation of the business, but it also helps to predict the future position of the business. The indication of financial health of business covers the role of leadership while keeping the business on track (Bryson, 2018; Nguyen, 2017). For better business performance, significant attention is required on both financial and non-financial resources.

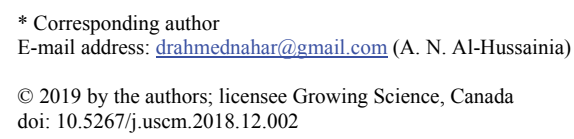


Performance measurement of the business is very much critical for the academic writers and managers in the firms. In its general context, the idea of firm performance (FP) is referred to the operational capability of the business or a company to satisfy its key shareholders in the marketplace (Smith \& Reece, 1999). Meanwhile, it expresses the organizational achievements either in long run or in the short run. In literature, the context of strategy and its association with the business performance has been examined for many years. Besides, scholars and researchers have clearly examined the importance of performance in business organizations (Brinckmann et al., 2010; Hughes \& Morgan, 2007). Many researchers consider the FP with the context of small and medium enterprises (SMEs) (Alasadi \& Abdelrahim, 2008; Collis \& Jarvis, 2002; Jarvis et al., 2000; Keil et al., 2008). It is also expressed that business performance measurement system (PBMS) is an important indicator in the field of management sciences. This system reflects the various factors which are impacting the performance of the business through quality indicators. The concept of supply chain management is considered as an important concept among the significant determinants of business performance in contemporary literature (Giunipero et al., 2008; Maurice, 2013; Purnama, 2014; Chielotam, 2015; Mowlaei, 2017; Albasu \& Nyameh, 2017; Maroofi et al., 2017; Kucukkocaoglu \& Bozkurt, 2018; Maldonado-Guzman et al., 2018). Numerous studies have implemented SCM in firms, which deals in retail business as well as in manufacturing (Li et al., 2006). Sandberg and Abrahamsson (2010) analyzed that SCM is impacting the performance of business firms, but still a significant gap is available to cope with business performance. Based on this idea, the present study aims to focus on the concept of SCM as a key determinant of business performance from the context of manufacturing firms, working in Kuwait. The manufacturing sector in Kuwait, deals with the petrochemicals, ammonia and fertilizers. Meanwhile, the contribution of the manufacturing sector towards the growth domestic product (GDP) has been from 5 to 6 percent over the last couple of years and the target of the government is to increase its contribution in GDP by more than its contribution witnessed in previous years. Different initiatives have been taken in recent years to promote the manufacturing sector in Kuwait, like the Kuwait Development Plan (KDP) having a worth of US $\$ 102$ billion. In addition, government has announced an increased budget of US $\$ 1.7$ billion for the manufacturing sector. Fig. 1 indicates value added of the manufacturing sector. Value added (\% of GDP) for Kuwait over recent years i.e. from 2010 to 2016, the figure indicates an increasing trend from 5.61 percent in 2011 to 7.27 percent of GDP in 2016.

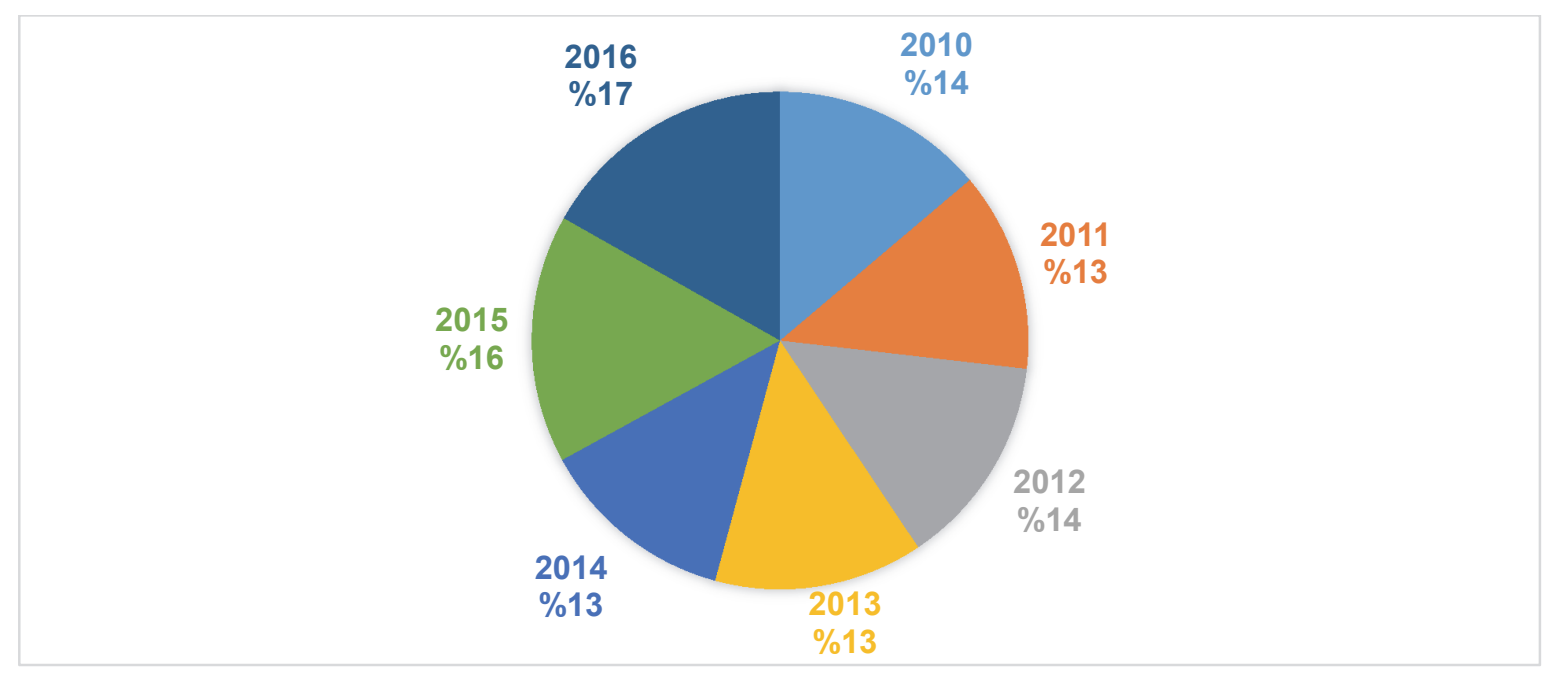

Fig. 1. Manufacturing sector value added \% of GDP in Kuwait Source: WDI (2018)

The rest of the paper is as follows. Section two deals with the review of the literature with context to business performance and supply chain. Section three describes the variables and their operational consideration. Section 4 indicates the sample and methodology being adopted in the analysis. Section 5 provides a detailed discussion about results and findings. Last section deals with the conclusion and future implications of the study. 


\section{Literature Review}

Business organizations work for the competitive advantage in the market, which enables them towards better financial performance (Lado et al., 1992). Due to its significance in the present literature, supply chain (SC) seems to be the important factor for the business organization in achieving sustainable edge over its rivals (Ploos van Amstel \& Starreveld, 1993). However, SC has shifted its role from shaping the structure of cost control to stability in its earnings. To deal with the customer satisfaction, businesses are involved with the core processes based on the supply chain. It can be expressed that the success of the business organization significantly depends on the SC process and activities. The review of the literature explains that little empirical evidence can be found regarding company's performance and its integration. The relationship between SC and business performance has been examined from the context of transaction cost theory. While some studies have investigated this relationship under organizational capability related to the resource-based view (RBV) (Wernerfelt, 1984). The assumption of RBV indicates that through organizational resources and capabilities, business firms achieve the competitive advantage in the market (Peng et al., 2008; Anigbogu \& Nduka, 2014; Santhi \& Gurunathan, 2014; Anyanwu et al., 2016; Jones \& Mwakipsile, 2017; Mosbah et al., 2017; Malarvizhi et al., 2018, Le et al., 2018). So, the indication of the SC can be viewed as both internal and external integrated capabilities that can directly impact the performance of the business firms. Besides, most studies have been conducted on the business performance of the firms in US, while ignoring the other cultures and business trends in various regions. For instance, China is considered to be a manufacturing hub for the global economy and plays an integral role in global supply chain and business performance (Hu \& Mao, 2002). The study conducted by Flynn et al. (2010) expresses the fact that manufacturers in China are creating significant value for both theoretical and empirical literature.

Prior studies on business and organizational performance have suggested a range of options to analyze the company's performance. For instance, according to Chen et al. (2004), Mahmood et al. (2016) and Javad and Basheer (2017) for overall attainment of strategic objectives, the performance of the firm should be the prime focus, as it is a necessary and a primary goal to make earnings for the shareholders. Various performance theories have considered the idea of financial outcomes to discuss organizational success (Boyer, 1999). However, some other academic researchers discussed the limitations of financial performance and its integration with the supply chain. For instance, according to Beamon and Balcik (2008) numerical performance of the business usually fails to define the system performance in a proper way and reaches a vague indicator for the qualitative evaluation. Many other researchers have cleared the idea that for the business performance, broader conceptualization is very much essential for both the operational and financial outcomes (Kaplan \& Norton, 2001, 2007; Vickery et al., 2003). In another study conducted by Tracey et al. (2005), along with financial performance they incorporated three broader measures of performance i.e. organizational capacity OC, supplier-oriented performance SOP, and customer-oriented performance COP. All these set of indicators collectively reflect the business performance. The concept of $\mathrm{OC}$ can be expressed as the business ability of a firm to perform in a productive way and link the business activities with the capacity of its operations through effective and significant transformation of input into output (Babakus et al., 1996). It is also known as the organizational intended performance or operational strength in the field of operation management. In the study of by Kusunoki et al. (1998), major categories of OC have been defined under the title of global, upper-level management, product or services, the information system of the business, and the relationship capabilities of the business. While taking resource based assumptions, almost 32 capabilities can be considered under OC (Lavie, 2006). Some other studies consider OC as dynamic capabilities which are referred to the structure, both internal and external competencies that deal with the competitive advantages of the business (Schreyögg \& Kliesch-Eberl, 2007; Wade \& Hulland, 2004). In addition, some literature findings on business and organizational performance, suggest a range of factors for measuring business performance. For instance, Saeidi et al. (2015) indicate that financial performance is a key focus of the overall business performance and is widely available in the existing body of the literature. 
In recent time, the supply chain has got significant attention as it is known as an integrated, systematic and strategic coordination of business functions. It covers the flow of materials, processes, and information across the business firms as well as units from supplier to the manufacturer for the improved business performance in the long-run (Ballou, 2007; Basheer et al., 2018). The idea of supply chain integration (SCI) is expressed in numerous studies as a degree to which a firm can strategically collaborate with the SC patterns and cooperatively manage the inter-organizational processes (Braunscheidel \& Suresh, 2009). Some authors explain that success of the company and supply chain activities are closely associated with each other (Fabbe-Costes et al., 2008). The view of Ahi and Searcy (2013) focused on the effect of SCM on financial performance, as various challenges exist for the measurement of supply chain practices in the field of business. Earlier studies have focused on the buyer-supplier association while reducing the role of supplier, developing a long-run relationship and continuous communication (Chen \& Paulraj, 2004). There is a considerable attention for the SC and firms' performance. For SC, the factors like strategic supplier partnership, information sharing, information quality, and customer relationship have been discussed in some studies. While some other studies have considered the factors of postponement, risk and reward sharing along with agreed vision and goals of the business and strategic supplier (Sundram et al., 2011). Meanwhile, factors in supply chain practices like management of customer and supplier, communication among the parties, quality and service indicators, and lean retailing practices are also observed for the organizational performance. Therefore, the focus of the present study is to investigate the effect of supply chain activities on sales growth, market value and other business performance measures.

\section{Variables and Methods}

The focus of the present study is to examine the impact of supply chain management on the business performance of manufacturing firms in Kuwait. The following variables are considered to measure the factors of SCM and business performance.The strategic relationship with the key supplier in the business firm has been studied for many years. In this regard, the selection of suppliers and business integration with such parties is known to be a significant decision for the business under supply chain management. Various studies have found that strategic sourcing can improve the performance of the supply chain. In the manufacturing sector, strategic sourcing is closely associated with the performance (Narasimhan \& Jayaram, 1998). They also expressed that strategic sourcing covers outsourcing and capability analysis of the supplier. To examine this association, a second order construct is developed for 215 manufacturing firms working in North America. Besides, the idea of strategic sourcing is also found to be significantly important determinant in defining the concept of knowledge creation and its sharing with the suppliers and retailers (Dewsnap \& Hart, 2004). As both the parties of suppliers and retailers are linked for the sharing of diverse knowledge, their combination can lead to the improved and unique category of knowledge for the better business performance. To measure the idea of strategic supplier partnership, four items have been added in the model as helping supplier for the improvement of quality, continuous improvement programs including suppliers, supplier partnership in planning and goal setting, and involvement of the supplier in new product development process (Hamister, 2012).

Information sharing refers to the sharing of non-public information with the supply chain by various parties. Several studies have empirically examined the role of information sharing in supply chain and got significant findings based on the stimulation approach. On the other hand, sharing of information between the manufacturer and other parties in the overall supply chain process can be very much useful (Iyer \& Ye, 2000). Numerous promotional activities can increase the demand in a specific time and can distort the activities of the supply chain. Because of this increased demand, lack of proper sharing of information between supplier and the manufacturer will likely to interrupt the business performance. Without the sharing of information, business performance cannot be achieved in an integrated way. In a study by Hamister and Suresh (2008), it is observed that the value of information sharing is high when the demand is autocorrelated with it. Moreover, it is observed that the scope of information sharing is significantly associated with the nature of the business (Towers \& Burnes, 2008). To analyze the factor of information sharing, the present study considers four items i.e. sharing of proprietary information by 
the supplier with the business, information from the supplier about key issues, exchange of information between the supplier and the business, and business planning based on shared information by the supplier. Information quality indicates the concept of true and accurate information sharing between the supplier and the business firm. Accurate and timely sharing of relevant information is an important indicator for performance enhancement in supply chain (Gavirneni et al., 1999). They stated that quality of information is a meaningful tool during the process of inventory management under different levels of capacity constraints. It was also found that distortion in information sharing can lead to the creation of bullwhip effect in the supply chain and finally increases the cost of the business, which in turn lowers the business performance (Lee et al., 1997). Under information quality, after careful understanding of the literature, four items namely; timely, accurate, complete, and reliable dimensions are added in the questionnaire.

The business performance is a multi-dimensional concept, covering a strong theoretical and empirical foundation for its management. Numerous studies have covered different factors to express their view regarding business performance. It has been studied under the areas of accounting, finance, marketing operation management and other areas in business and economy. Industry leadership defines the business performance of a leading organization through its higher sales growth, more earnings and better market share compared with its rivals (Ferguson \& Stokes, 2002). Future outlook of the company is also a key indicator for measuring company's performance (Faulkner \& Schwartz, 2009; Feldstein, 2000). Whereas, overall response to the competition in the market, the success rate in the new product and overall business performance are significant determinants for assessing the business performance. The level of productivity of the process and employees (Quinn, 2018), sales growth (Brush et al., 2000), profit growth (Morgan et al., 2009) and overall market value of the company (McConnell \& Muscarella, 1985) are some other factors to express business performance. Analyses of the present study have considered all these dimensions to express business performance in the manufacturing sector, while more focus is paid to the factors of sales growth and current market value (Suryanto et al., 2018)

\section{Sample and Methods of Analysis}

To analyze the impact of supply chain management on business performance, individuals from various manufacturing units linked to the supply chain and business processes were selected. A sample of 314 respondents was finalized for the empirical analysis of the study. To get the results, a structural model was developed by incorporating the factors of supply chain and business performance. The path of the analysis was based on the confirmatory factor analysis (CFA), structure equation modelling (SEM) and finally the regression analysis for the impact of the supply chain on sales growth and current market value of the manufacturing firms. In the very first step, overall factor analyses were performed. In the $2^{\text {nd }}$ step, structural equation modelling technique was applied for an overall model of the study. While seperate regression analyses, specifically for the sales growth and current market value was also taken. The items of supply chain and business performance were measured on five points Likert scale, ranging from strongly disagree to strongly agree, and from bottom to top, respectively.

\section{Results and Discussions}

Table 1 indicates the trends of the data set through a descriptive analysis of the study. To measure the factors of supply chain management, four factors of strategic supplier partnership (SSP1-SSP4, information quality (IQ1-IQ4), information sharing (IS1-IS4) and information intensity (INTS1INTS2) have been added to the model. To measure the business performance, various items like industry leadership (INDL), future outlook (FOUTLK), overall response to competition (ORC), overall business performance (OBP), employee's productivity (EP), process productivity (PPRO), sales growth (SG), profit growth (PG), company's market value (CMV), and success rate in the launching of new product (SRNP) have been added in the model. The overall observation for all the items is 314 , indicating that all the respondents have provided their meaningful responses. For strategic supplier partnership, all four indicators have a mean score of above 4, which explains that respondents are agreed upon all the four items of SSP i.e. helping the supplier to improve the quality of the product 
(SSP1), continuous improvement programs including suppliers (SSP2), inclusion of key supplier in planning and goal settings (SSP3), and involvement of suppliers in new product development (SSP4). For information quality (IQ), it is observed that for the timely information (IQ1), and complete information (IQ3), respondents were not clear and gave neutral responses for the statements, providing a mean score of 3 approximately. However, in the case of accurate information (IQ2) and reliable information (IQ4), responses were in favor of the statement that business firm is sharing exact and full information with its supplier. For information sharing (IS), respondents are agreed with the findings that the supplier is sharing proprietary information with the business (IS1; Mean 4.30).

The $2^{\text {nd }}$ item indicates that the supplier is informing the business about those issues which can affect the performance of the business (IS2). The mean score for IS2 is 4.00 expressing that the respondents are agreed with this statement of information sharing. For IS3, the mean score of 4.37 explains that responses are aligned with sharing of information regarding the core business processes by the supplier. For the last indicator of IS4 (exchange of information for business planning) mean score of 4.50 indicates a significant information sharing between the supplier and the business.

The key focus of the study is to examine the impact of supply chain management practices on business performance indicators. The first indicator of business performance is industry leadership and respondents have been requested to provide their opinions while considering the position of their business. A five-point scale ranging from bottom-1, on average-2, above average-3, reasonable-4, and finally top-5 is considered. The mean score for industry leadership (INDL), indicates that the overall position of business is above average. For future outlook (FOUTLK), mean score of 3.26 represents a reasonable position for overall manufacturing of business firms. The main item of overall business performance (OBP), reflects a good position with a mean score of 4.21 , and similar position is witnessed for the success rate of new product launching. The mean values of the factor of employee productivity and process productivity (PPRO) turned out to be 3.15 and 4.86, respectively, exhibiting a reasonable position in the industry as per the recorded responses. For sales growth, the responses exhibit a reasonable position of the business. While for the profit growth (PG), overall situation is very good with a mean score of 4.82, approximately. Business occupies a reasonable position for the item of company's market value (CMV). As per the last indicator of business performance (success rate in new product launching SRNP), its mean value turned out to be 4.60, exhibiting a good position for the success.

\section{Table 1}

Descriptive Statistics

\begin{tabular}{|c|c|c|c|c|c|}
\hline & $\mathrm{N}$ & Minimum & Maximum & Mean & Std. Deviation \\
\hline SSP1 & 314 & 1.00 & 5.00 & 4.2930 & .29022 \\
\hline SSP2 & 314 & 1.00 & 5.00 & 4.0828 & .21735 \\
\hline SSP3 & 314 & 1.00 & 5.00 & 4.8981 & .22375 \\
\hline SSP4 & 314 & 1.00 & 5.00 & 4.8694 & .31548 \\
\hline IQ1 & 314 & 1.00 & 5.00 & 3.0287 & .37845 \\
\hline IQ2 & 314 & 1.00 & 5.00 & 4.5541 & .30320 \\
\hline IQ3 & 314 & 1.00 & 5.00 & 3.0446 & .24271 \\
\hline IQ4 & 314 & 1.00 & 5.00 & 4.8726 & .30483 \\
\hline IS1 & 314 & 1.00 & 5.00 & 4.3057 & .24691 \\
\hline IS2 & 314 & 1.00 & 5.00 & 4.0064 & .31832 \\
\hline IS3 & 314 & 1.00 & 5.00 & 4.3726 & .21414 \\
\hline IS4 & 314 & 1.00 & 5.00 & 4.5000 & .14521 \\
\hline INDL & 314 & 1.00 & 5.00 & 4.1911 & .24933 \\
\hline FOUTLK & 314 & 1.00 & 5.00 & 3.2675 & .21955 \\
\hline ORC & 314 & 1.00 & 5.00 & 4.0828 & .27127 \\
\hline OBP & 314 & 1.00 & 5.00 & 4.2102 & .24111 \\
\hline $\mathrm{EP}$ & 314 & 1.00 & 5.00 & 3.1561 & .34396 \\
\hline PPRO & 314 & 1.00 & 5.00 & 4.8694 & .35379 \\
\hline SG & 314 & 1.00 & 5.00 & 4.8726 & .38096 \\
\hline PG & 314 & 1.00 & 5.00 & 4.8280 & .17034 \\
\hline CMV & 314 & 1.00 & 5.00 & 3.7516 & .12852 \\
\hline SRNP & 314 & 1.00 & 5.00 & 4.6019 & .21655 \\
\hline Valid N (listwise) & 314 & & & & \\
\hline
\end{tabular}


After the findings of descriptive statistics, factor analysis has been performed to check either the selected indicators under each of the variable can be considered for the structural model or not. For SSP, the factor loading is 0.59 for SSP1, 0.67 for SSP2, 0.71 for SSP3 and 0.67 for SSP4, respectively. It expresses a reasonable factor loading and provides enough argument for the consideration of SSP for structural model. For information sharing, the factor loading is above .50 for all the four indicators. For IS1-4, all items have factor loading score of above .50. Figs. (1-2) indicate the factor loading for the various items of supply chain management. Besides, for business performance, the minimum factor loading is 0.61 which comes from the product productivity and the maximum is 0.81 , which belongs to the item ORC. While, for the sales growth and product growth factor loading is .79 expressing a good contribution in defining the overall business performance. The rest of the indicators under business performance has considerably good factor loadings.
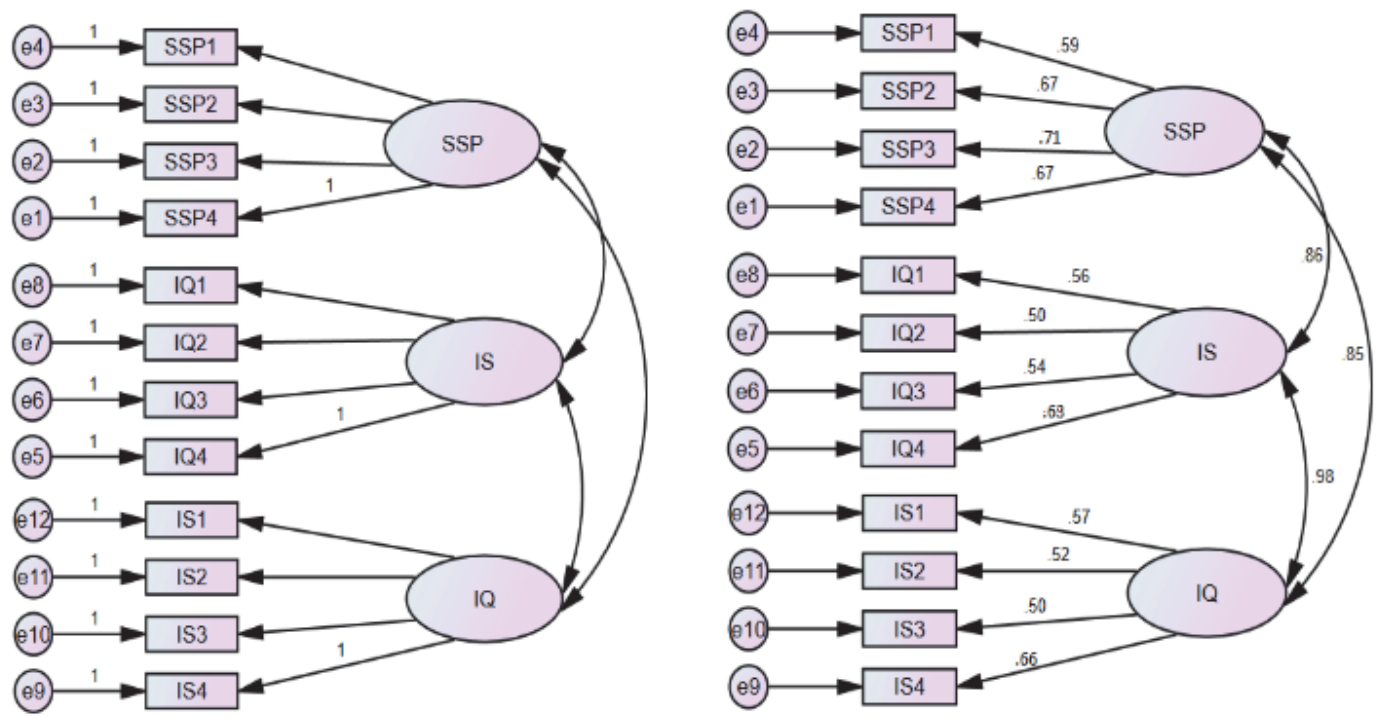

Fig. 2. CFA for supply chain Items
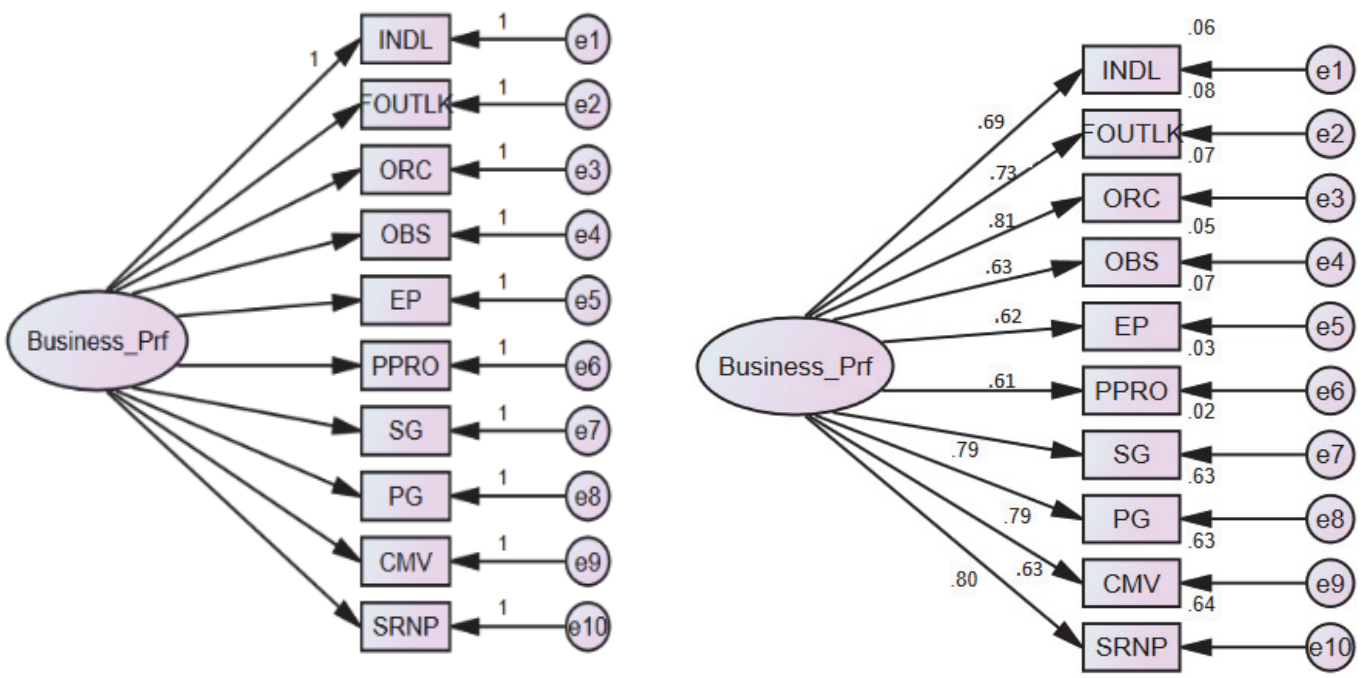

Fig. 3. CFA for business performance measurements

After the factor analysis, structural model of the study has been developed and presented in Fig. 4. For supply chain management, three items under the title of strategic supplier partnership, information sharing, and information quality with four items each have been considered. For business performance overall 12 items are added including the sales growth, product growth and current market value. The findings for the structural model are presented in Table 2. 


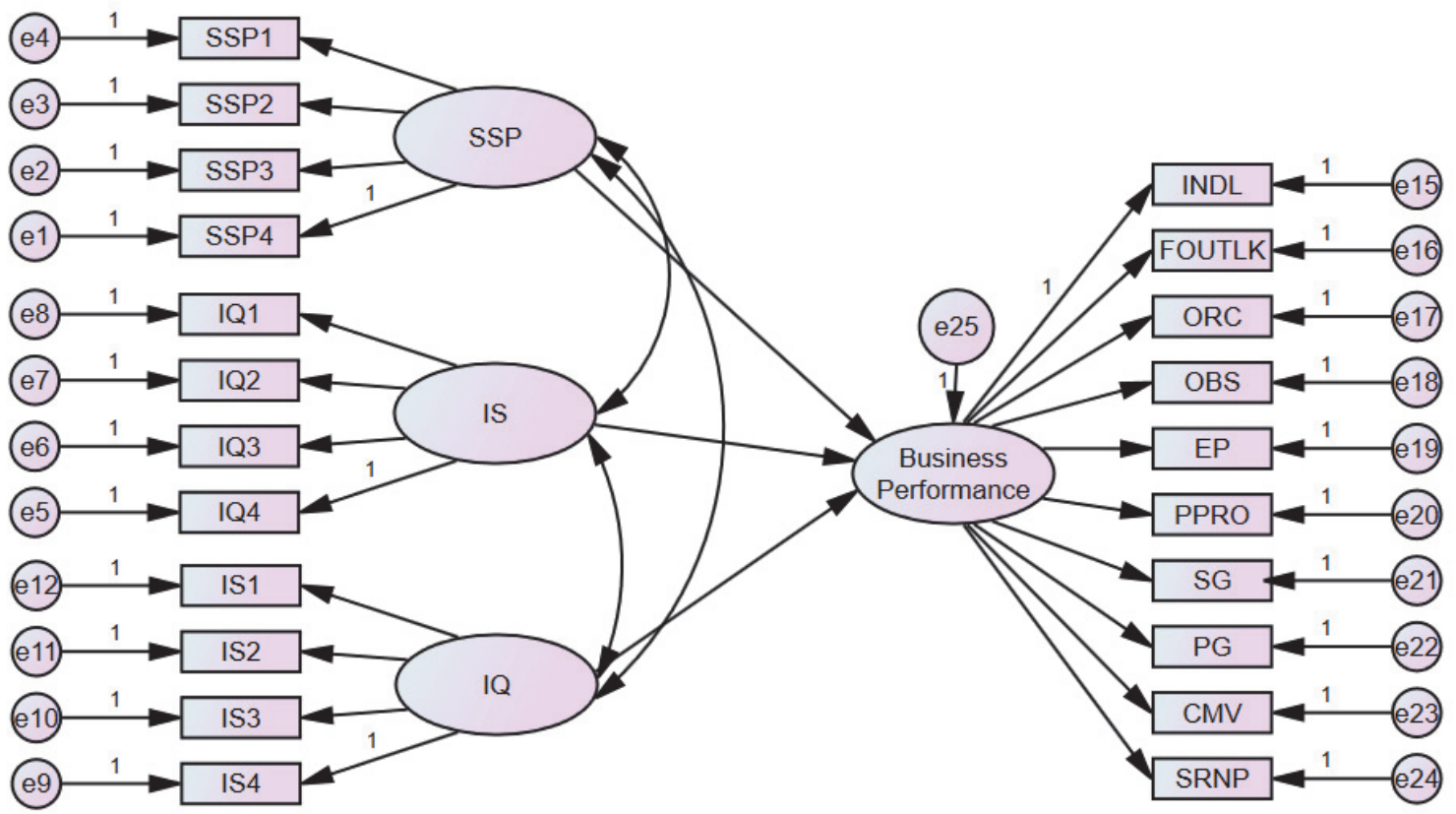

Fig. 4. Model of the Study

Table 2 indicates the findings under the structural analysis of the study through unstandardized and standardized estimation method in AMOS-22. The effect of strategic supplier partnership (SSP) indicates that a unit change in its value creates an overall positive impact of .30 in the value of business performance including sales growth, product growth and current market value of selected firms in Kuwait. The value of standard error is .061 for SSP with the critical ratio of 4.91 . The overall impact of SSP on business performance is positive and significant when the level of significance is 1 percent, which indicates that SSP has a significant positive impact on the business performance. This positive impact of strategic supplier partnership is very important for the product growth, sales growth and other selected indicators for the business performance. For the information sharing (IS), the combined effect of 4 items on overall business performance including sales growth, product growth, and current market value is .56. This implies that information sharing is a positive determinant of business performance. The value of the standard error is 0.132 with the CR of 4.24 , which implies that significant evidence is available to conclude that IS significantly and positively affect the performance of the firm. However, it is found that business performance is insignificantly affected by the information quality for the whole sample of the study. This insignificant association between IQ and business performance implies that there is a need for re-evaluation of key indicators of information quality which in turn would have a significant impact on the business performance in Kuwait. To analyze the individual contribution of each item in supply chain management and business performance, individual coefficients are also presented in Table 2. For SSP1-3, IS1-IS3, and IQ1-3, it is found that all items significantly contribute towards information sharing. Meanwhile, industry leadership (INDL), future outlook (FOUTLK), overall response to competition (ORC), overall business performance (OBP), employee productivity $(\mathrm{EP})$, process productivity (PPRO), sales growth (SG), profit growth (PG), company market value (CMV), and success rate in the launching of new product (SRNP) have significant contribution in determining the business performance. The key findings exhibit that sales growth, product growth and current market value are significantly determined by the business performance with the coefficients of $0.810,0.660$ and 0.614 , respectively. With the adjustment of standard error, the findings for the standard regression estimates are presented under Table 3, indicating a positive sign for all the coefficients of the model. 
Table 3

Regression Weights: (Group number 1 - Default model)

\begin{tabular}{|c|c|c|c|c|c|c|}
\hline Variables & Directions & Variables & Estimate & S.E. & C.R. & $\mathrm{P}$ \\
\hline Business_Prf. & $\leftarrow$ & SSP & .30 & .061 & 4.91 & $* * *$ \\
\hline Business_Prf. & $\leftarrow$ & IS & .56 & .132 & 4.24 & $* * *$ \\
\hline Business_Prf. & $\leftarrow$ & IQ & .554 & 6.225 & .088 & .803 \\
\hline SSP4 & $\leftarrow$ & SSP & \multicolumn{4}{|c|}{ Regression Weight $=1.000$} \\
\hline SSP3 & $\leftarrow$ & SSP & .640 & .095 & 6.733 & $* * *$ \\
\hline SSP2 & $\leftarrow$ & SSP & .955 & .102 & 9.327 & $* * *$ \\
\hline SSP1 & $\leftarrow$ & SSP & .885 & .105 & 8.453 & $* * *$ \\
\hline IQ4 & $\leftarrow$ & IS & \multicolumn{4}{|c|}{ Regression Weight 1.000} \\
\hline IQ3 & $\leftarrow$ & IS & 1.028 & .151 & 6.791 & $* * *$ \\
\hline IQ2 & $\leftarrow$ & IS & .990 & .154 & 6.439 & $* * *$ \\
\hline IQ1 & $\leftarrow$ & IS & 1.148 & .168 & 6.821 & $* * *$ \\
\hline IS4 & $\leftarrow$ & IQ & \multicolumn{4}{|c|}{ Regression weight $=1.000$} \\
\hline IS3 & $\leftarrow$ & IQ & 1.986 & .493 & 4.029 & $* * *$ \\
\hline IS2 & $\leftarrow$ & IQ & 2.190 & .542 & 4.044 & $* * *$ \\
\hline IS1 & $\leftarrow$ & IQ & 2.239 & .544 & 4.115 & $* * *$ \\
\hline INDL & $\leftarrow$ & Business_Prf. & \multicolumn{4}{|c|}{ Regression Weight 1.000} \\
\hline FOUTLK & $\leftarrow$ & Business_Prf. & 1.056 & .136 & 7.779 & $* * *$ \\
\hline ORC & $\leftarrow$ & Business_Prf. & 1.050 & .139 & 7.541 & $* * *$ \\
\hline OBS & $\leftarrow$ & Business_Prf. & .943 & .132 & 7.125 & $* * *$ \\
\hline EP & $\leftarrow$ & Business_Prf. & .807 & .135 & 5.965 & $* * *$ \\
\hline PPRO & $\leftarrow$ & Business_Prf. & .974 & .142 & 6.852 & $* * *$ \\
\hline SG & $\leftarrow$ & Business_Prf. & .810 & .138 & 5.855 & $* * *$ \\
\hline PG & $\leftarrow$ & Business_Prf. & .660 & .116 & 5.673 & $* * *$ \\
\hline CMV & $\leftarrow$ & Business_Prf. & .614 & .112 & 5.503 & $* * *$ \\
\hline SRNP & $\leftarrow$ & Business_Prf. & .660 & .120 & 5.493 & $* * *$ \\
\hline
\end{tabular}

Table 4

Standardized Regression Weights: (Group number 1 - Default model)

\begin{tabular}{cccc}
\hline Variables & Directions & Variables & Estimate \\
\hline Business_Prf. & $\leftarrow$ & SSP & .037 \\
Business_Prf. & $\leftarrow$ & IS & .053 \\
Business_Prf. & $\leftarrow$ & IQ & .688 \\
SSP4 & $\leftarrow$ & SSP & .660 \\
SSP3 & $\leftarrow$ & SSP & .454 \\
SSP2 & $\leftarrow$ & SSP & .681 \\
SSP1 & $\leftarrow$ & IQ & .595 \\
IQ4 & $\leftarrow$ & IQ & .503 \\
IQ3 & $\leftarrow$ & IQ & .543 \\
IQ2 & $\leftarrow$ & IQ & .499 \\
IQ1 & $\leftarrow$ & IS & .547 \\
IS4 & $\leftarrow$ & IS & .271 \\
IS3 & $\leftarrow$ & IS & .507 \\
IS2 & $\leftarrow$ & IS & .515 \\
IS1 & $\leftarrow$ & Business_Prf. & .557 \\
INDL & $\leftarrow$ & Business_Prf. & .560 \\
FOUTLK & $\leftarrow$ & Business_Prf. & .606 \\
ORC & $\leftarrow$ & Business_Prf. & .578 \\
OBS & $\leftarrow$ & Business_Prf. & .532 \\
EP & $\leftarrow$ & Business_Prf. & .420 \\
PPRO & $\leftarrow$ & Business_Prf. & .504 \\
SG & $\leftarrow$ & Business_Prf. & .411 \\
PG & $\leftarrow$ & Business_Prf. & .395 \\
CMV & $\leftarrow$ & Business_Prf. & .381 \\
SRNP & & .380 \\
\hline & & &
\end{tabular}

Table 5 presents the robust regression coefficients for both the outcome factors; sales growth and current market value of the business. For the first item of strategic supplier partnership, it is observed that business firms are helping their suppliers for the improvement of quality which in turn creates a positive and significant impact on sales growth and current market value. For SSP2, it is observed that continuous improvement programs with the help of the suppliers also positively and significantly influence the sales growth and market value in the manufacturing sector of Kuwait. For the strategic 
partnership with the supplier in planning and goal setting (SSP3), the same positive and significant influence has been recorded on sales growth and market value. It implies that whenever the suppliers will be under consideration for the strategic planning, it will significantly contribute towards the improved performance. For the information sharing, only the impact of IS2 (keeping the business fully informed by the supplier) has shown its insignificant impact on sales growth and current market value. For the items under information quality, the impact of accurate information is found to be significantly negative on the current market value of the business. It implies that information accuracy needs to be observed as it is negatively affecting the market value of the stock. For timely information IQ1, significant and positive impact on both performance measures is recorded. For the sales growth, the value of robust $\mathrm{R}$-square is .861 percent and for current market value, it is .791 percent respectively.

Table 5

Regression Findings for Sales Growth and current market Value through SCM

\begin{tabular}{|c|c|c|}
\hline & (1) & (2) \\
\hline VARIABLES & Sales Growth & CMV \\
\hline \multirow[t]{2}{*}{$\overline{\text { SSP1 }}$} & $0.205^{* *}$ & $0.567 * * *$ \\
\hline & $(0.0579)$ & $(0.0599)$ \\
\hline \multirow[t]{2}{*}{ SSP2 } & $0.0750 * * *$ & $0.0773 * *$ \\
\hline & $(0.0683)$ & $(0.0713)$ \\
\hline \multirow[t]{2}{*}{ SSP3 } & $0.136 * *$ & $0.0875 * * *$ \\
\hline & $(0.0622)$ & $(0.0632)$ \\
\hline \multirow[t]{2}{*}{ SSP4 } & $0.00907 * *$ & $0.0263 * *$ \\
\hline & $(0.0696)$ & $(0.0630)$ \\
\hline \multirow[t]{2}{*}{ IS1 } & $0.118^{* *}$ & -0.0149 \\
\hline & $(0.0547)$ & $(0.0583)$ \\
\hline \multirow[t]{2}{*}{ IS2 } & 0.0151 & 0.141 \\
\hline & $(0.0592)$ & $(0.0606)$ \\
\hline \multirow[t]{2}{*}{ IS3 } & $0.112 *$ & 0.0128 \\
\hline & $(0.0635)$ & $(0.0643)$ \\
\hline \multirow[t]{2}{*}{ IS4 } & $0.00114 * *$ & $.0122 * * *$ \\
\hline & $(0.0625)$ & $(0.0596)$ \\
\hline \multirow[t]{2}{*}{ IQ1 } & $0.0395 * *$ & $0.152 * *$ \\
\hline & $(0.0644)$ & $(0.0664)$ \\
\hline \multirow[t]{2}{*}{ IQ2 } & -0.0693 & $-0.110^{*}$ \\
\hline & $(0.0633)$ & $(0.0586)$ \\
\hline \multirow[t]{2}{*}{ IQ3 } & $0.153 * *$ & $0.0550 * *$ \\
\hline & $(0.0616)$ & $(0.0653)$ \\
\hline \multirow[t]{2}{*}{ IQ4 } & $0.125 * *$ & $0.0727 * * *$ \\
\hline & $(0.0594)$ & $(0.0685)$ \\
\hline \multirow[t]{2}{*}{ Constant } & $2.725 * * *$ & $2.382 * * *$ \\
\hline & $(0.347)$ & $(0.352)$ \\
\hline Observations & 314 & 314 \\
\hline $\mathrm{R}$-squared & 0.861 & 0.791 \\
\hline
\end{tabular}

Robust standard errors in parentheses

$* * * \mathrm{p}<0.01, * * \mathrm{p}<0.05, * \mathrm{p}<0.1$

\section{Conclusion, Implications and Future Research}

In the present study, an empirical investigation is conducted to check the impact of supply chain management on the various indicators of business performance for the manufacturing firms, working in the region of Kuwait. Based on the existing literature, an empirical relationship has been developed, for the identified factors of supply chain and business performance. For supply chain, three factors under the title of strategic supplier partnership, information sharing, and information quality were considered. For the variable of business performance 10 factors have been included; namely product growth, sales growth and current market value of the stock. The findings of the study have indicated that strategic supplier partnership, and information sharing significantly determine the business performance. These findings are in accordance with the results of Gawankar et al. (2013). The positive impact of supply chain practices on firm's performance is similar to the findings of Chow et al. (2008) and Prajogo and Olhager (2012), in which they majorly focused on various business groups in different regions. These findings were analyzed, subject to business performance taking sales growth, product growth and current market value as key determinants of business performance. To analyze the findings, 
factor analysis has been conducted in the first step to check the individual contribution of each factor for their further consideration in the structural analysis of the study. The findings under CFA indicates that all the selected items have meaningful factor loadings and no item was deleted as minimum factor loading was above 0.50. In addition, under the structural analysis, it is observed that all selected items of business performance have their significant contribution in defining the overall business performance. However, the effect of information sharing on business performance is more as compared with strategic supplier partnership for the whole sample of the study. Researchers in the field of business management can use these findings to generate upcoming ideas for further empirical studies. Moreover, managers who are linked to supply chain can focus such practices that can help them improve the business performance. Managers can consider the factors of supply chain other than the ones included in the present study, in order to improve the performance of the organization. For instance, information integrity is another indicator which can be considered for the measurement of business performance.

As per the managerial implications, the findings of the study indicate that supply chain plays an integrated role to support the business firm for better performance, these findings are consistent with the studies of Gharakhani and Mousakhani (2012) and Kannan and Tan (2005). Such findings can give an in-depth understanding to business managers regarding the strategic role of the supply chain. For the financial managers \& analysts, factors like sales growth, product growth and current market value are very important for business performance. However, this study has some limitations as well. For instance, it is found that some respondents have not carefully filled the questionnaire may be because of their personal schedules or due to working shifts. Issues arising from the questionnaire responses are known as response errors. In further studies on supply chain and business performance, more attention is needed to avoid response errors which can be emerged because of the comprehensive statements in the questionnaire. Improving the questionnaire pattern and removing ambiguous meanings of statements can help the researchers get clear responses from the respondents. Moreover, a variety of external and internal factors are responsible in affecting the business performance.

In addition, the current study is confined to the manufacturing sector of Kuwait. However, it provides linkages for the future research by explaining its objectives in the services as well as in other sectors of Kuwait.

\section{References}

Ahi, P., \& Searcy, C. (2013). A comparative literature analysis of definitions for green and sustainable supply chain management. Journal of cleaner production, 52, 329-341.

Alasadi, R., \& Abdelrahim, A. (2008). Analysis of small business performance in Syria. Education, Business and Society: Contemporary Middle Eastern Issues, 1(1), 50-62.

Albasu, J., \& Nyameh, J. (2017). Relevance of stakeholders theory, organizational identity theory and social exchange theory to corporate social responsibility and employees performance in the commercial banks in Nigeria. International Journal of Business, Economics and Management, 4(5), 95-105.

Anigbogu, U. E., \& Nduka, E. K. (2014). Stock market performance and economic growth: Evidence from Nigeria employing vector error correction model framework. The Economics and Finance Letters, 1(9), 90-103.

Anyanwu, J. O., Okoroji, L. I., Ezewoko, O. F., \& Nwaobilor, C. A. (2016). The impact of training and development on workers performance in Imo state. Global Journal of Social Sciences Studies, 2(2), 51 71.

Babakus, E., Cravens, D. W., Grant, K., Ingram, T. N., \& LaForge, R. W. (1996). Investigating the relationships among sales, management control, sales territory design, salesperson performance, and sales organization effectiveness. International Journal of Research in Marketing, 13(4), 345-363.

Ballou, R. H. (2007). Business logistics/supply chain management: planning, organizing, and controlling the supply chain. Pearson Education India.

Basheer, M., Siam, M., Awn, A., \& Hussan, S. (2019). Exploring the role of TQM and supply chain practices for firm supply performance in the presence of information technology capabilities and supply 
chain technology adoption: A case of textile firms in Pakistan. Uncertain Supply Chain Management, 7(2), 275-288.

Beamon, B. M., \& Balcik, B. (2008). Performance measurement in humanitarian relief chains. International Journal of Public Sector Management, 21(1), 4-25.

Boyer, K. K. (1999). Evolutionary patterns of flexible automation and performance: a longitudinal study. Management Science, 45(6), 824-842.

Braunscheidel, M. J., \& Suresh, N. C. (2009). The organizational antecedents of a firm's supply chain agility for risk mitigation and response. Journal of Operations Management, 27(2), 119-140.

Brinckmann, J., Grichnik, D., \& Kapsa, D. (2010). Should entrepreneurs plan or just storm the castle? A meta-analysis on contextual factors impacting the business planning-performance relationship in small firms. Journal of business Venturing, 25(1), 24-40.

Brush, T. H., Bromiley, P., \& Hendrickx, M. (2000). The free cash flow hypothesis for sales growth and firm performance. Strategic Management Journal, 21(4), 455-472.

Bryson, J. M. (2018). Strategic planning for public and nonprofit organizations: A guide to strengthening and sustaining organizational achievement. John Wiley \& Sons.

Chen, I. J., \& Paulraj, A. (2004). Towards a theory of supply chain management: the constructs and measurements. Journal of Operations Management, 22(2), 119-150.

Chen, I. J., Paulraj, A., \& Lado, A. A. (2004). Strategic purchasing, supply management, and firm performance. Journal of Operations Management, 22(5), 505-523.

Chielotam, A. N. (2015). Oguamalam masquerade performance beyond aesthetics. Humanities and Social Sciences Letters, 3(2), 63-71.

Chow, W. S., Madu, C. N., Kuei, C.-H., Lu, M. H., Lin, C., \& Tseng, H. (2008). Supply chain management in the US and Taiwan: An empirical study. Omega, 36(5), 665-679.

Collis, J., \& Jarvis, R. (2002). Financial information and the management of small private companies. Journal of Small Business and Enterprise Development, 9(2), 100-110.

Dewsnap, B., \& Hart, C. (2004). Category management: a new approach for fashion marketing? European Journal of Marketing, 38(7), 809-834.

Fabbe-Costes, N., Jahre, M., \& Roussat, C. (2008). Supply chain integration: the role of logistics service providers. International Journal of Productivity and Performance Management, 58(1), 71-91.

Faulkner, E. B., \& Schwartz, R. J. (2009). High performance pigments. John Wiley \& Sons.

Feldstein, M. (2000). Aspects of global economic integration: Outlook for the future. National Bureau of Economic Research.

Ferguson, A., \& Stokes, D. (2002). Brand name audit pricing, industry specialization, and leadership premiums post-Big 8 and Big 6 mergers. Contemporary Accounting Research, 19(1), 77-110.

Flynn, B. B., Huo, B., \& Zhao, X. (2010). The impact of supply chain integration on performance: A contingency and configuration approach. Journal of Operations Management, 28(1), 58-71.

Gavirneni, S., Kapuscinski, R., \& Tayur, S. (1999). Value of information in capacitated supply chains. Management Science, 45(1), 16-24.

Gawankar, S., Kamble, S. S., \& Verma, R. (2013). Effect of supply chain management practices on supply chain profitability: an empirical investigation using structural equation modelling in Indian retail sector. International Journal of Services and Operations Management, 16(2), 145-173.

Gharakhani, D., \& Mousakhani, M. (2012). Knowledge management capabilities and SMEs' organizational performance. Journal of Chinese Entrepreneurship, 4(1), 35-49.

Giunipero, L. C., Hooker, R. E., Joseph-Matthews, S., Yoon, T. E., \& Brudvig, S. (2008). A decade of SCM literature: past, present and future implications. Journal of Supply Chain Management, 44(4), 66-86.

Hamister, J. W. (2012). Supply chain management practices in small retailers. International Journal of Retail \& Distribution Management, 40(6), 427-450.

Hamister, J. W., \& Suresh, N. C. (2008). The impact of pricing policy on sales variability in a supermarket retail context. International Journal of Production Economics, 111(2), 441-455.

Hu, T., \& Mao, Z. (2002). Effects of cigarette tax on cigarette consumption and the Chinese economy. Tobacco Control, 11(2), 105-108.

Hughes, M., \& Morgan, R. E. (2007). Deconstructing the relationship between entrepreneurial orientation and business performance at the embryonic stage of firm growth. Industrial Marketing Management, $36(5), 651-661$. 
Iyer, A. V., \& Ye, J. (2000). Assessing the value of information sharing in a promotional retail environment. Manufacturing \& Service Operations Management, 2(2), 128-143.

Jarvis, R., Curran, J., Kitching, J., \& Lightfoot, G. (2000). The use of quantitative and qualitative criteria in the measurement of performance in small firms. Journal of Small Business and Enterprise Development, $7(2), 123-134$

Javed, M. A., \& Basheer, M. F. (2017). Impact of external factors on bank profitability. EPRA International Journal of Research and Development, 2(5), 1-11.

Jones Osasuyi, O., \& Mwakipsile, G. (2017). Working capital management and managerial performance in some selected manufacturing firms in Edo state Nigeria. Journal of Accounting, Business and Finance Research, 1(1), 46-55.

Kannan, V. R., \& Tan, K. C. (2005). Just in time, total quality management, and supply chain management: understanding their linkages and impact on business performance. Omega, 33(2), 153-162.

Kaplan, R. S., \& Norton, D. P. (2001). Transforming the balanced scorecard from performance measurement to strategic management: Part I. Accounting Horizons, 15(1), 87-104.

Kaplan, R. S., \& Norton, D. P. (2007). Using the balanced scorecard as a strategic management system. Harvard Business Review, 85(7/8), 150.

Keil, T., Maula, M., Schildt, H., \& Zahra, S. A. (2008). The effect of governance modes and relatedness of external business development activities on innovative performance. Strategic Management Journal, 29(8), 895-907.

Kucukkocaoglu, G., \& Bozkurt, M. A. (2018). Identifying the effects of mergers and acquisitions on Turkish banks performances. Asian Economic and Financial Review, 6(3), 235-244.

Kusunoki, K., Nonaka, I., \& Nagata, A. (1998). Organizational capabilities in product development of Japanese firms: a conceptual framework and empirical findings. Organization Science, 9(6), 699-718.

Lado, A. A., Boyd, N. G., \& Wright, P. (1992). A competency-based model of sustainable competitive advantage: Toward a conceptual integration. Journal of Management, 18(1), 77-91.

Lavie, D. (2006). The competitive advantage of interconnected firms: An extension of the resource-based view. Academy of Management Review, 31(3), 638-658.

Le, H. L., Vu, K. T., Du, N. K., \& Tran, M. D. (2018). Impact of working capital management on financial performance: The case of Vietnam. International Journal of Applied Economics, Finance and Accounting, 3(1), 15-20.

Lee, H. L., Padmanabhan, V., \& Whang, S. (1997). Information distortion in a supply chain: The bullwhip effect. Management Science, 43(4), 546-558.

Li, S., Ragu-Nathan, B., Ragu-Nathan, T., \& Rao, S. S. (2006). The impact of supply chain management practices on competitive advantage and organizational performance. Omega, 34(2), 107-124.

Mahmood, A., Hussan, S. G., Sarfraz, M., Abdullah, M. I., \& Basheer, M. F. (2016). Rewards satisfaction, perception about social status and commitment of Nurses in Pakistan. European Online Journal of Natural and Social Sciences, 5(4), 1049.

Malarvizhi, C. A., Nahar, R., \& Manzoor, S. R. (2018). The strategic performance of Bangladeshi private commercial banks on post implementation relationship marketing. International Journal of Emerging Trends in Social Sciences, 2(1), 28-33.

Maldonado-Guzman, G., Marin-Aguilar, J., \& Garcia-Vidales, M. (2018). Innovation and performance in Latin-American small family firms. Asian Economic and Financial Review, 8(7), 1008-1020.

Maroofi, F., Ardalan, A. G., \& Tabarzadi, J. (2017). The effect of sales strategies in the financial performance of insurance companies. International Journal of Asian Social Science, 7(2), 150-160.

Maurice, I. U. (2013). Impact of product development and innovation on organisational performance. International Journal of Management and Sustainability, 2(12), 220-230.

McConnell, J. J., \& Muscarella, C. J. (1985). Corporate capital expenditure decisions and the market value of the firm. Journal of Financial Economics, 14(3), 399-422.

Morgan, N. A., Slotegraaf, R. J., \& Vorhies, D. W. (2009). Linking marketing capabilities with profit growth. International Journal of Research in Marketing, 26(4), 284-293.

Mosbah, A., Serief, S. R., \& Wahab, K. A. (2017). Performance of family business in Malaysia. International Journal of Social Sciences Perspectives, 1(1), 20-26.

Mowlaei, M. (2017). The impact of AFT on export performance of selected Asian developing countries. Asian Development Policy Review, 5(4), 253-261. 
Narasimhan, R., \& Jayaram, J. (1998). Causal linkages in supply chain management: an exploratory study of North American manufacturing firms. Decision Sciences, 29(3), 579-605.

Nguyen, S. T. (2017). Sustainment Strategies Small Business Owners Use for More Than 5 Years.

Pandiyan Kaliani Sundram, V., Razak Ibrahim, A., \& Chandran Govindaraju, V. (2011). Supply chain management practices in the electronics industry in Malaysia: Consequences for supply chain performance. Benchmarking: An International Journal, 18(6), 834-855.

Peng, M. W., Wang, D. Y., \& Jiang, Y. (2008). An institution-based view of international business strategy: A focus on emerging economies. Journal of International Business Studies, 39(5), 920-936.

Ploos van Amstel, W., \& Starreveld, D. W. (1993). Does your company need a logistical executive? The International Journal of Logistics Management, 4(1), 49-58.

Prajogo, D., \& Olhager, J. (2012). Supply chain integration and performance: The effects of long-term relationships, information technology and sharing, and logistics integration. International Journal of Production Economics, 135(1), 514-522.

Purnama, C. (2014). Improved performance through empowerment of small industry. Journal of Social Economics Research, 1(4), 72-86.

Quinn, R. E. (2018). Productivity and the process of organizational improvement: Why we cannot talk to each other Public Sector Performance (pp. 9-19). Routledge.

Reed, D. (2002). Corporate governance reforms in developing countries. Journal of Business Ethics, 37(3), 223-247.

Saeidi, S. P., Sofian, S., Saeidi, P., Saeidi, S. P., \& Saaeidi, S. A. (2015). How does corporate social responsibility contribute to firm financial performance? The mediating role of competitive advantage, reputation, and customer satisfaction. Journal of Business Research, 68(2), 341-350.

Sandberg, E., \& Abrahamsson, M. (2010). The role of top management in supply chain management practices. International Journal of Retail \& Distribution Management, 38(1), 57-69.

Santhi, N. S., \& Gurunathan, K. B. (2014). Fama-French three factors model in Indian mutual fund market. Asian Journal of Economics and Empirical Research, 1(1), 1-5.

Schreyögg, G., \& Kliesch-Eberl, M. (2007). How dynamic can organizational capabilities be? Towards a dual-process model of capability dynamization. Strategic Management Journal, 28(9), 913-933.

Smith, T. M., \& Reece, J. S. (1999). The relationship of strategy, fit, productivity, and business performance in a services setting. Journal of Operations Management, 17(2), 145-161.

Suryanto, T., Haseeb, M., \& Hartani, N. H. (2018). The Correlates of Developing Green Supply Chain Management Practices: Firms Level Analysis in Malaysia. International Journal of Supply Chain Management, 7(5), 316.

Towers, N., \& Burnes, B. (2008). A composite framework of supply chain management and enterprise planning for small and medium-sized manufacturing enterprises. Supply Chain Management: An International Journal, 13(5), 349-355.

Tracey, M., Lim, J.-S., \& Vonderembse, M. A. (2005). The impact of supply-chain management capabilities on business performance. Supply Chain Management: An International Journal, 10(3), 179-191.

Turner, R. K. (1988). Pluralism in environmental economics: A survey of the sustainable economic development debate. Journal of Agricultural Economics, 39(3), 352-359.

Vickery, S. K., Jayaram, J., Droge, C., \& Calantone, R. (2003). The effects of an integrative supply chain strategy on customer service and financial performance: an analysis of direct versus indirect relationships. Journal of Operations Management, 21(5), 523-539.

Wade, M., \& Hulland, J. (2004). The resource-based view and information systems research: Review, extension, and suggestions for future research. MIS quarterly, 28(1), 107-142.

WDI. (2018). Manufacturing, value added (\% of GDP). from https://data. worldbank.org/indicator/NV.IND.MANF.ZS?contextual=max\&end=2016\&locations=KW \&start $=2010 \&$ view $=$ chart

Wernerfelt, B. (1984). A resource-based view of the firm. Strategic Management Journal, 5(2), 171-180.

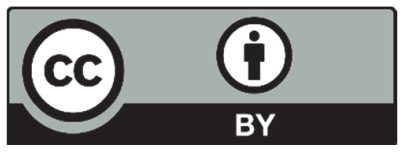

(C) 2019 by the authors; licensee Growing Science, Canada. This is an open access article distributed under the terms and conditions of the Creative Commons Attribution (CC-BY) license (http://creativecommons.org/licenses/by/4.0/). 